Research Article

\title{
Adsorption of Uranium(VI) from Aqueous Solution by Modified Rice Stem
}

\author{
Zhang Xiao-teng, Jiang Dong-mei, Xiao Yi-qun, Chen Jun-chang, Hao Shuai, \\ and Xia Liang-shu
}

School of Nuclear Science and Technology, University of South China, Hengyang 421001, China

Correspondence should be addressed to Xia Liang-shu; publicxls@163.com

Received 13 November 2018; Revised 20 January 2019; Accepted 27 February 2019; Published 23 April 2019

Academic Editor: Doina Humelnicu

Copyright (c) 2019 Zhang Xiao-teng et al. This is an open access article distributed under the Creative Commons Attribution License, which permits unrestricted use, distribution, and reproduction in any medium, provided the original work is properly cited.

\begin{abstract}
The biosorption is an effective and economical method to deal with the wastewater with low concentrations of uranium. In this study, we present a systematic investigation of the adsorption properties, such as the kinetics, thermodynamics, and mechanisms, of modified rice stems. The rice stems treated with $0.5 \mathrm{~mol} / \mathrm{L} \mathrm{NaOH}$ solutions show higher removal percentage of uranium than those unmodified under the conditions of initial $\mathrm{pH}(\mathrm{pH}=4.0)$, absorbent dosage $(5-8 \mathrm{~g} / \mathrm{L})$, temperature $(T=298 \mathrm{~K})$, and adsorption equilibrium time ( $t=180 \mathrm{~min}$ ). The removal percentage of uranium(VI) decreases with increasing initial concentration of uranium(VI). The Langmuir isotherm model, which suggests predominant monolayered sorption, is better than Freundlich and Temkin models to elucidate the adsorption isotherm of adsorbed uranium. Kinetic analyses indicate that the uranium(VI) adsorption of the modified rice stem is mainly controlled by surface adsorption. The pseudo-second-order kinetic model, with the correlation coefficient of $R^{2}=0.9992$, fits the adsorption process much better than other kinetic models (e.g., pseudo-second-order kinetic model, Elovich kinetic model, and intraparticle diffusion model). The thermodynamic parameters $\Delta G^{0}, \Delta H^{0}$, and $\Delta S^{0}$ demonstrate that the adsorption of uranium(VI) is an endothermic and spontaneous process, which can be promoted by temperature. The adsorption of uranium can change the morphology and the structure characteristics of the modified rice stem through interaction with the adsorption sites, such as $\mathrm{O}-\mathrm{H}, \mathrm{C}=\mathrm{O}, \mathrm{Si}=\mathrm{O}$, and $\mathrm{P}-\mathrm{O}$ on the surface.
\end{abstract}

\section{Introduction}

Uranium is a heavy metal with significant chemical toxicity and radioactivity. Since the leakage of radio nuclides in the Japan's Fukushima Daiichi nuclear plant, the uranium contamination has attracted more and more attentions. Large amounts of uranium released from aqueous solutions of natural deposits, uranium mill tailings, and ammunition shave migrated into the environment $[1,2]$. If uraniumcontaining wastewater is drained directly without appropriate treatment, the uranium would be absorbed by the humic and mineral materials and gradually enter the biological-geochemical circulation, finally breaking the organism's normal metabolism and even endangering human health and the ecosystem's safety. For example, the uranium leaking into the environment can cause extensive human diseases (e.g., skin erythema, trichomadesis, nephritis, leukaemia, and bone cancer) and even deaths [3]. Therefore, it is critically important to prevent the uranium of wastewater from transporting into the environment.

Many methods, such as chemical precipitationcrystallizing, ion exchange, solvent extraction, and film separation [4-9], have so far been developed to deal with the uranium-containing wastewater. However, these methods are not effective and economical, especially when treating large amounts of wastewater containing the low contents of the radioactive ionic material [10]. Therefore, it is urgent to develop low-cost and easily obtained uranium sorbents for efficient treatment of uranium-containing wastewater. Biosorption has been considered to be a useful method as it utilizes various natural materials of biological origin, including bacteria, fungi yeast and algae, to remove metal ions 
from solutions [11-14]. Compared with the traditional methods, the biosorption has the following advantages: (1) the fast sorption kinetic and high selectivity for removing low concentrations of heavy metals (e.g., uranium); (2) low energy consumption; (3) abundant sources of biosorbents; (4) simple operation; (5) wide operation ranges of $\mathrm{pH}$ and temperature; and (6) good reproduction of adsorbents.

The treatment of heavy metals through biosorption has been extensively studied in the past decades. The researches mainly focus on the selectivity of the biosorbents, the biosorption kinetics and thermodynamics, the biosorption mechanism, and large-scale experiments [15-18]. Currently, some potential biomaterials with higher adsorption capacity of heavy metals have been adopted to treat uranium-containing wastewater. From an economic point of view, researchers mainly use various disposed products from industries or agricultural farms as adsorbents. Thus, it is necessary to seek the most promising biosorbents from an extremely large pool of easily available and inexpensive biomaterials. Disposed agricultural products such as biosorbents are considered to be one of the most potential adsorbents [19]. Until now, various disposed agricultural biosorbents, such as wood powder, wheat straw, grapefruit peel, coir pith, and banyan leaves [19-22], have been investigated for the adsorption of uranium(VI). These biosorbents have been identified as an efficient kind of sorbent for adsorption of uranium.

There are abundant low-cost rice stems from agricultural wastes. At present, the world annual output amounts of the rice stem are over 17 billion tons. Large amounts of rice stem are burnt as fertilizer, resulting in environmental pollution and waste of resources. The rice stem, which is composed of rice hemicellulose, cellulose, lignin, and protein, can be used to efficiently solve the environmental pollution caused by metals in an economical and eco-friendly way because it has unique characteristics to remove the metal ion from aqueous solution. Some researchers have recognized the feasibility of rice stem for the treatment of wastewater. For example, Liu [23] and Amin et al. [24] suggested that rice stem had a great ability to enrich organic contaminants (e.g., methylene blue and phenol). However, while Sugashini [25] studied the sorption of heavy metal ions $\left(\mathrm{Hg}^{2+}, \mathrm{Cr}^{3+}\right.$, and $\left.\mathrm{Mo}^{3+}\right)$ by rice stem, very few studies have reported the rice stem as a biosorbent [26] for treatment of the wastewater with low contents of uranium.

In this study, the rice stem is chosen to deal with the wastewater with low contents of uranium. The main aim of this study is to investigate the effects of different experimental conditions, such as modified methods, $\mathrm{pH}$, adsorbent dose, initial concentration, sorption equilibrium time, and temperature. In addition, the thermodynamics and mechanism of sorption were also systematically investigated based on the batch experiments of uranium(VI) ions adsorption. Our study suggests that the modified rice stem is a kind of promising biosorbent material to efficiently and economically remove uranium(VI) from the wastewater.

\section{Materials and Methods}

2.1. Materials. All the chemicals and reagents used in this study were analytically pure. The rice stem was supplied by
Hengyang County, Hunan Province. Uranium stock solution was prepared by dissolving an certain amount of $\mathrm{UO}_{2}\left(\mathrm{NO}_{3}\right)_{2} \cdot 6 \mathrm{H}_{2} \mathrm{O}$ in distilled water, and the initial $\mathrm{pH}$ of the uranium(VI) solution was adjusted by addition of $10 \% \mathrm{HCl}$ and $10 \% \mathrm{NaOH}$.

2.2. Preparation of Rice Stem. Rice stems were cut into $5 \mathrm{~cm}$ segments and then washed in running water twice and in distilled water once. The washed rice stems were dried in the oven at $80^{\circ} \mathrm{C}$ for $24 \mathrm{~h}$. Then, the solids were ground into 60 mesh.

2.3. Batch Sorption Experiments. $40 \mathrm{~mL}$ uranium(VI) ion solution was put into a $250 \mathrm{~mL}$ Erlenmeyer flask. The $\mathrm{pH}$ of solution was adjusted by addition of $\mathrm{HCl}$ and $\mathrm{NaOH}$ in each experiment. A certain amount of rice stem was added into the Erlenmeyer flask placed in the constant temperature water bath oscillator. The experiment was carried out for $120 \mathrm{~min}$. The suspension was separated by centrifuging at $4000 \mathrm{rpm}$ for $10 \mathrm{~min}$. Then, the supernatant liquid was filtered, and the filtrate was used to analyze the concentration of uranium by 5 -Br-PADAP (used as a chromogenic agent in the spectrophotometric method). The uranium(VI) removal percentage $R(\%)$ and adsorption capacity $Q_{t}(\mathrm{mg} / \mathrm{g})$ were determined using the following equations, respectively:

$$
\begin{aligned}
R & =\frac{\left(C_{0}-C_{t}\right)}{C_{0}} \times 100 \%, \\
Q_{t} & =\frac{\left(C_{0}-C_{t}\right)}{m} \times V,
\end{aligned}
$$

where $C_{0}$ and $C_{t}$ represent the initial concentration and concentration at time $t$, respectively, with the unit of $\mathrm{mg} / \mathrm{L}$; $V$ is the volume of uranium solution $(\mathrm{mL})$; and $m$ is the mass of the sorbent (g).

\section{Results and Discussion}

3.1. Effect of the Modified Materials. $4 \mathrm{~g}$ of rice stem was added into $50 \mathrm{~mL}$ mixture of $\mathrm{NaOH}, \mathrm{HCl}, \mathrm{H}_{2} \mathrm{O}_{2}$, ammonium hydroxide, and citric acid solutions and then stirred for $24 \mathrm{~h}$. The resulted mixture was filtered and washed with distilled water at the same time, until the $\mathrm{pH}$ of the rice stem was close to neutral. Then, the modified rice stem was dried in the oven at $80^{\circ} \mathrm{C}$ for $24 \mathrm{~h}$. The color changes of modified rice stem are shown in Figure 1. In this study, the effect of the modified materials on the adsorption capacity of rice stem is investigated using ion solutions of $10 \mathrm{mg} \cdot \mathrm{L}^{-1}$ uranium(VI) at $\mathrm{pH}=5.0 .2 \mathrm{~g}$ of different modified rice stems was added into aqueous solution containing $10 \mathrm{mg} / \mathrm{L}$ of uranium(VI) at room temperature, where the reaction lasted for $120 \mathrm{~min}$. The experimental results are given in Table 1.

Figure 1 shows the difference in color and texture of modified rice stem after modification through different ways. The $\mathrm{NaOH}$-modified rice stems show lighter color and slimmer and softer texture. The rice stem treated with $0.5 \mathrm{~mol} / \mathrm{L} \mathrm{NaOH}$ has the highest uranium removal rate 


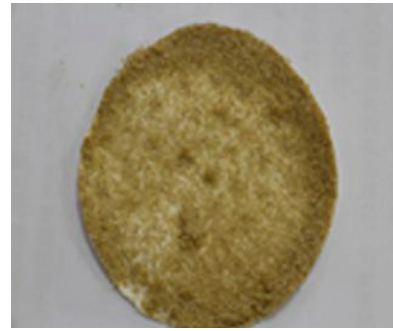

(a)

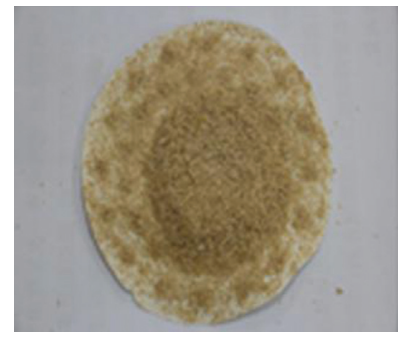

(e)

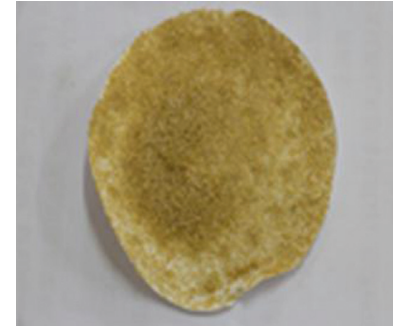

(b)

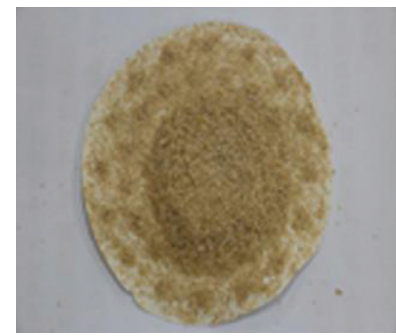

(f)

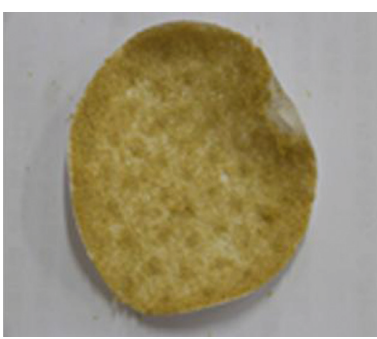

(c)

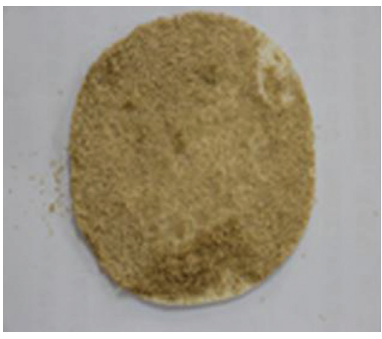

(g)

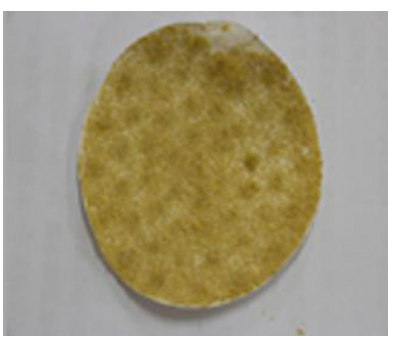

(d)

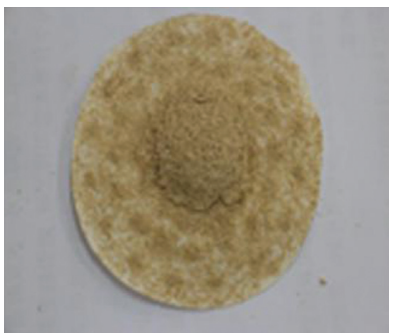

(h)

FIGURE 1: The hue changes of rice stem before and after modification by the modified materials: (a) $0.25 \mathrm{~mol} / \mathrm{L} \mathrm{NaOH}$; (b) $0.5 \mathrm{~mol} / \mathrm{L} \mathrm{NaOH}$; (c) $1.0 \mathrm{~mol} / \mathrm{L} \mathrm{NaOH}$; (d) $1.5 \mathrm{~mol} / \mathrm{L} \mathrm{NaOH}$; (e) $\mathrm{HCl}$; (f) $\mathrm{H}_{2} \mathrm{O}_{2}$; (g) ammonium hydroxide; (h) citric acid.

TABLE 1: Effect of modified materials on adsorption of uranium(VI).

\begin{tabular}{lcc}
\hline Modified methods & $\begin{array}{c}\text { Removal rate } \\
(\%)\end{array}$ & $\begin{array}{c}\text { Adsorption capacity } \\
(\mathrm{mg} / \mathrm{g})\end{array}$ \\
\hline- & 76.11 & 1.52 \\
$0.25 \mathrm{~mol} / \mathrm{L} \mathrm{NaOH}$ & 92.00 & 1.84 \\
$0.5 \mathrm{~mol} / \mathrm{L} \mathrm{NaOH}$ & 94.55 & 1.89 \\
$1 \mathrm{~mol} / \mathrm{L} \mathrm{NaOH}$ & 93.84 & 1.88 \\
$1.5 \mathrm{~mol} / \mathrm{L} \mathrm{NaOH}$ & 87.68 & 1.75 \\
$\mathrm{HCl}$ & 89.46 & 1.79 \\
$\mathrm{H}_{2} \mathrm{O}_{2}$ & 92.74 & 1.85 \\
Ammonium hydroxide & 91.98 & 1.84 \\
Citric acid & 79.09 & 1.58 \\
\hline
\end{tabular}

(94.55\%) because of many $\mathrm{SiO}_{2}$ and nonaromatic esters in the surface of modified rice stem [27], which were dissolved out by $\mathrm{NaOH}$. In this kind of modified rice stem, the cross-linked network structure among cellulose, hemicellulose, and lignin were broken and then exposed to the surface of sorbents [28]. Thus, the uranium removal percentage increases as a result of increasing specific surface area.

3.2. Effect of the Initial $\mathrm{pH}$. The $\mathrm{pH}$ of solution has been considered as one of the most important parameters affecting uranium ion sorption because it can change the ionic forms of the uranyl ions. The effect of the initial $\mathrm{pH}$ on the adsorption capacity of modified rice stem is investigated using ion solutions of $10 \mathrm{mgL}^{-1}$ uranium(VI), where the $\mathrm{pH}$ values $(\mathrm{pH}=1.4-7.0)$ are adjusted using $\mathrm{HCl}$ and $\mathrm{NaOH}$ at room temperature. The solutions were mixed with $0.2 \mathrm{~g}$ modified rice stem, where the reaction lasted for $120 \mathrm{~min}$. The experimental results of the initial $\mathrm{pH}$ are shown in Figure 2, which indicates that uranium(VI) removal percentage and adsorption capacity reaches the maximum value $(97.6 \%$ and



FIgURE 2: The effect of $\mathrm{pH}$ on adsorption of uranium(VI) by modified rice stem.

$1.95 \mathrm{mg} / \mathrm{g}$ at $\mathrm{pH}=4.0$, respectively) with $\mathrm{pH}$ values increasing from 3.0 to 4.0 . But the uranium removal percentage and adsorption capacity decrease when $\mathrm{pH}$ values increase from 4.0 to 7.0 . The results demonstrate that $\mathrm{pH}=4$ is the most efficient $\mathrm{pH}$ value for removal of $\mathrm{U}(\mathrm{VI})$ by modified rice stem. It could explain the differences between the existence species of the uranium ion and the cell's surface activity sites at different $\mathrm{pH}$ values [29]. At lower $\mathrm{pH}$ values, $\mathrm{H}^{+}\left(\right.$or $\left.\mathrm{H}_{3} \mathrm{O}^{+}\right)$ competed with $\mathrm{UO}_{2}{ }^{2+}$ for the active sites on the surface of the modified rice stem [30]. Uranium can exist in many forms in different acid environments, such as $\mathrm{UO}_{2}{ }^{2+},\left[\mathrm{UO}_{2}(\mathrm{OH})\right]^{+}$, $\left[\left(\mathrm{UO}_{2}\right)_{2}(\mathrm{OH})_{2}\right]^{2+}$, and $\left[\left(\mathrm{UO}_{2}\right)_{3}(\mathrm{OH})_{5}\right]^{+}[2]$. The rice stem modified by $0.5 \mathrm{~mol} / \mathrm{L} \mathrm{NaOH}$ has a high sorption capacity in the $\mathrm{pH}$ range of $\mathrm{pH}=3-4$. The adsorption capacity decreases with the increasing $\mathrm{pH}$ value $(\mathrm{pH}>4)$, due to the formation of other forms or precipitation [22]. The main form of $\mathrm{UO}_{2}{ }^{2+}$ in 
solution is $\mathrm{UO}_{2}(\mathrm{OH})_{2}$, which deposited on the surface of banyan leaf cells and interfered with the enrichment of cells that cause the losing of absorbent efficacy. Therefore, $\mathrm{pH}=4$ is suggested as the best $\mathrm{pH}$ value for further sorption experiments.

3.3. Effect of the Contact Time. The effect of the contact time is investigated in the time range of $20-200 \mathrm{~min} .0 .2 \mathrm{~g}$ of modified rice stem was added into $10 \mathrm{mg} \cdot \mathrm{L}^{-1}$ uranium(VI) solution. The results are shown in Figure 3, which indicates an increase in the removal of $\mathrm{U}(\mathrm{VI})$ by modified rice stem with the time up to $200 \mathrm{~min}$. This increase is most pronounced during the first $180 \mathrm{~min}$ but becomes smaller with further increase in time, demonstrating that the sorption process almost reaches equilibrium at about $180 \mathrm{~min}$. Thus, all the mixtures of the sorbent and the solution were shaken for at least $180 \mathrm{~min}$ to ensure full equilibrium in subsequent experiments.

3.4. Effect of the Adsorbent Dose. The effect of adsorbent dose is investigated in the dose range of $1.25-8.75 \mathrm{mg} / \mathrm{L}$ at room temperature (Figure 4), where the solution was shaken for $180 \mathrm{~min}$, and the initial concentration of the solution was $10 \mathrm{mg} \cdot \mathrm{L}^{-1}$ at $\mathrm{pH}=4$.

Figure 4 shows that the removal percentage increases, but the adsorption capacity of uranium(VI) decreases with the increasing adsorbent dose. It is worth noting that the removal percentage and the adsorption capacity of uranium(VI) are nearly constant when the adsorbent dose reaches $7.5 \mathrm{mg} \cdot \mathrm{L}^{-1}$. This may be because the adsorption capacity of modified rice stem per unit area decreases as a result of the aggregation of excessive adsorbent [21].

3.5. Adsorption Kinetics. To assess the kinetic characteristics of uranium(VI) ions of the adsorption process, we adopted several kinetic models (i.e., pseudo-first-order kinetic model, pseudo-second-order kinetic model, Elovich kinetic model, and intraparticle diffusion model) to calculate the parameters $[31,32]$. The expressions of models are shown in the following equations:

pseudo first order kinetic model: $\ln \left(q_{e}-q_{t}\right)=\ln q_{e}-k_{1} t$,

pseudo second order kinetic model: $\frac{t}{q_{t}}=\frac{1}{k_{2} q_{e}^{2}}+\frac{t}{q_{e}}$,

Elovich kinetic model: $q_{t}=b+k_{E} \cdot \ln t$,

intraparticle diffusion model: $q_{t}=k_{i} t^{0.5}+C$,

where $k_{1}\left(\min ^{-1}\right), k_{2}(\mathrm{mg} /(\mathrm{g} \cdot \mathrm{min})), k_{E}(\mathrm{mg} /(\mathrm{g} \cdot \mathrm{min})), k_{i}$ $\left(\min ^{-1}\right)$, and $k_{d}\left(\mathrm{mg} /\left(\mathrm{g} \cdot \mathrm{min}^{\mathrm{n}}\right)\right)$ are the adsorption rate constant; $q_{t}(\mathrm{mg} / \mathrm{g})$ is the amount of adsorbed uranium at time $t ; q_{e}(\mathrm{mg} / \mathrm{g})$ is the maximum adsorption capacity; and $b$ and $\mathrm{C}$ are the constant.

The results of each kinetic model are given in Table 2, which shows that the correlative parameter $R^{2}$ of the



Figure 3: Effect of time on uranium adsorption by modified rice stem.



Figure 4: Effect of the adsorbent dose by modified rice stem.

TABLE 2: Adsorption kinetic parameters of uranium(VI) adsorption by modified rice stem.

\begin{tabular}{lccccc}
\hline & \multicolumn{6}{c}{ Adsorption kinetic parameters } & \multirow{2}{*}{$R^{2}$} \\
& $k$ & $q$ & $C$ & $b$ & \\
\hline Pseudo-first-order & 0.00094 & 16.679 & - & - & 0.9673 \\
Pseudo-second-order & 0.0721 & 1.9467 & - & - & 0.9992 \\
Intraparticle diffusion & 0.0302 & - & 1.4779 & - & 0.9885 \\
Elovich & 0.1308 & - & - & 1.1923 & 0.9610 \\
\hline
\end{tabular}

pseudo-second-order kinetic model is the best among the five kinetic models mentioned above, and the calculated equilibrium adsorption amount was $1.9467 \mathrm{mg} / \mathrm{g}$, which was close to the experimental result of $1.8903 \mathrm{mg} / \mathrm{g}$. This demonstrates that the pseudo-second-order kinetic model best fits the adsorption process of uranium(VI) ions. In addition to the physical and chemical processes, there may be other adsorption mechanisms of uranium(VI) by modified rice stem because the fitted curve of the intraparticle diffusion model does not pass across the origin of coordinate $[28,33]$. 
3.6. Effect of the Initial Uranium(VI) Concentration. The effect of initial uranium ion concentration is investigated at room temperature under the conditions of the initial $\mathrm{pH}$ $(\mathrm{pH}=4.0)$ and uranium contents $\left(5-60 \mathrm{mg} \cdot \mathrm{L}^{-1}\right)$, using $0.2 \mathrm{~g}$ modified rice stem, which was shaken for $180 \mathrm{~min}$. The results about the effect of the initial uranium concentration are shown in Figure 5.

As shown in Figure 5, the uranium(VI) removal percentage slightly decreases from $97.8 \%$ to $94.7 \%$ with the increasing initial uranium concentration from $5 \mathrm{mg} / \mathrm{L}$ to $60 \mathrm{mg} / \mathrm{L}$, where the adsorption capacity, however, increases from $0.97 \mathrm{mg} / \mathrm{g}$ to $11.36 \mathrm{mg} / \mathrm{g}$. This may be because most uranium(VI) ions interact with the sufficient surface active sites of modified rice stem, resulting in higher uranium(VI) removal percentages at lower uranium(VI) concentrations; however, the excessive uranium(VI) ions in the solutions increase with further increase in the uranium concentration, which would cause the increase of adsorption amount at higher uranium(VI) concentrations.

3.7. Equilibrium Adsorption Isotherms. Langmuir, Freundlich, and Temkin isotherms models are generally used to study the adsorption equilibrium [20]. The Langmuir isotherm model assumes that the sorption is monolayered, and the attractive force of the intermolecular sharply depresses with the increasing distance [34]. The Freundlich isotherm model is robust to elucidate the surface heterogeneity and the exponential distribution of active sites [35]. On the contrary, the Temkin isotherm model suggests that the adsorption heat decreases with the reduction of adsorption quantity [36]. The expressions of the Langmuir, Freundlich, and Temkin models are given by the following equations:

Langmuir isotherms model: $\frac{c_{e}}{q_{e}}=\frac{c_{e}}{q_{m}}+\frac{1}{b q_{m}}$,

Freundlich isotherms model: $\ln q_{e}=\frac{1}{n} \ln c_{e}+\ln K_{f}$,

Temkin isotherms model: $q_{e}=a \ln K_{T}+a \ln C_{e}$,

where $q_{e}$ is the amount of adsorbed metal ions, $\mathrm{mg} / \mathrm{g} ; c_{e}$ is the equilibrium concentration in solution, $\mathrm{mg} / \mathrm{L} ; q_{m}$ is the amount of maximum adsorbed metal ions, $\mathrm{mg} / \mathrm{g} ; b$ is the Langmuir adsorption model constant; $K_{f}$ and $n$ are the Freundlich adsorption model constants; and $K_{T}$ and $a$ are the Temkin adsorption model constants. With $c_{e} / q_{e}$ as the ordinate and $c_{e}$ as the abscissa, a straight line can be obtained, the slope of the line is $1 / q_{m}$, and the vertical intercept of the line is $1 / b q_{m}$. The parameters of the remaining two equations can be calculated in the same way. The parameters of the Langmuir, Freundlich, and Temkin isotherm models for the adsorption of uranium ions by rice stem are shown in Table 3 .

Table 3 shows that the model parameters (e.g., $q_{m}$ in the Langmuir model, $K_{f}$ in the Freundlich model, and $a$ and $K_{T}$ in the Temkin model) increases slightly with increasing temperature, demonstrating that the uranium adsorption process by rice stem is endothermic. On the contrary, the



FIGURE 5: Effect of the initial uranium concentration by modified rice stem.

comparison between the correlation parameters $R^{2}$ of the three isotherm models (Langmuir, Freundlich, and Temkin) (Table 3) shows that the Langmuir model is better than Freundlich and Temkin models to elucidate the adsorption isotherm of adsorbed uranium. Therefore, it can be concluded that the predominant adsorption of uranium by modified rice stem is monolayered.

3.8. Effect of Temperature. The effect of temperature on adsorption properties of uranium is shown in Figure 6. As can be seen from Figure 6, the removal percentage of uranium increases slightly with temperature in the Trange of $298-318 \mathrm{~K}$, demonstrating that the adsorption reaction is more pronounced at higher temperature. This may be because (1) some new active sites are produced with heating and (2) the metal ions have stridden across the energy barrier to endure diffusion transmission or resist concentration gradient [28]. Thus, $T=298 \mathrm{~K}$ is suggested as the most appropriate temperature for adsorption experiments.

3.9. Adsorption Thermodynamics. The thermodynamic parameters of the sorption process are calculated according to the following equations at different temperatures [37]. The values of thermodynamic parameters are showed in Table 4:

$$
\begin{aligned}
\Delta G^{0} & =-R T \ln K_{d}, \\
\ln K_{d} & =\frac{\Delta S^{0}}{R}-\frac{\Delta H}{R T}, \\
\Delta G^{0} & =\Delta H^{0}-T \Delta S^{0},
\end{aligned}
$$

where $\Delta G^{0}$ is the Gibbs free energy, $\mathrm{kJ} / \mathrm{mol} ; R$ is the ideal gas constant, with the value of $8.314 \mathrm{~kJ} /(\mathrm{mol} \cdot \mathrm{K})$; $T$ is the absolute temperature; $K_{d}$ is the thermodynamic stability constant; $C_{e}$ is the equilibrium concentration, $\mathrm{mg} \cdot \mathrm{L}^{-1} ; K_{0}$ is the distribution coefficient; $\Delta S^{0}$ is the standard entropy, $\mathrm{kJ} /(\mathrm{mol} \cdot \mathrm{K})$; and $\Delta H^{0}$ is the enthalpy, $\mathrm{kJ} / \mathrm{mol}$. 
TABLE 3: Parameters of different isothermal models of uranium(VI) adsorption by rice stem.

\begin{tabular}{|c|c|c|c|c|c|c|c|c|c|}
\hline \multirow{2}{*}{$T(\mathrm{~K})$} & \multicolumn{3}{|c|}{ Langmuir model } & \multicolumn{3}{|c|}{ Freundlich model } & \multicolumn{3}{|c|}{ Temkin model } \\
\hline & $q_{m}$ & $b$ & $R^{2}$ & $K_{f}$ & $n$ & $R^{2}$ & $a$ & $K_{T}$ & $R^{2}$ \\
\hline 298 & 18.0857 & 0.5200 & 0.9854 & 5.0343 & 1.3550 & 0.9934 & 3.0980 & 7.8284 & 0.9309 \\
\hline 308 & 18.2883 & 0.5107 & 0.9899 & 5.5823 & 1.3651 & 0.9844 & 3.11 & 8.991 & 0.9450 \\
\hline 318 & 18.9753 & 0.5012 & 0.9903 & 6.3818 & 1.3254 & 0.9767 & 3.2576 & 9.818 & 0.9583 \\
\hline
\end{tabular}

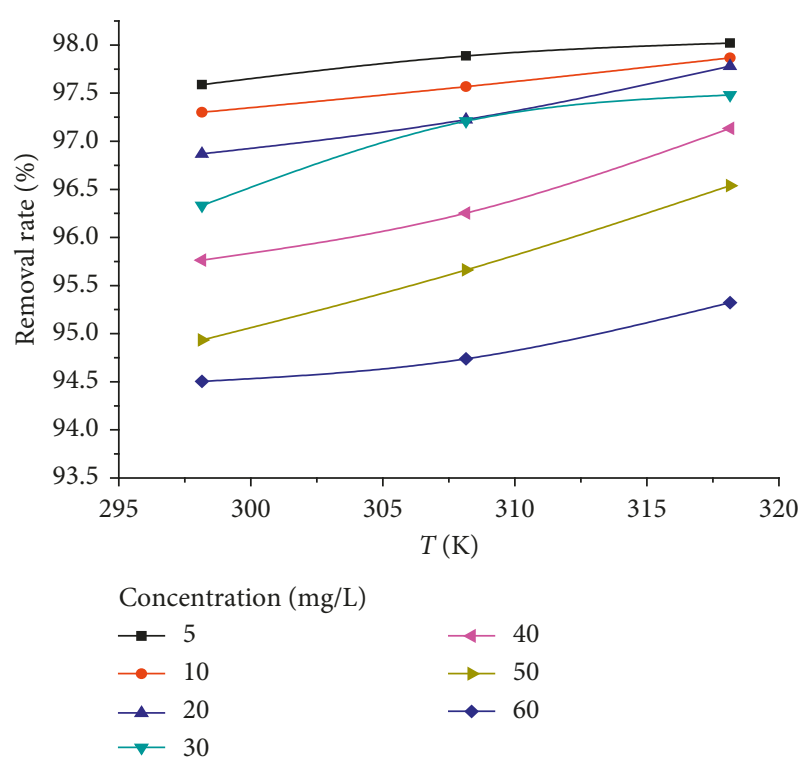

FIgURE 6: Effect of temperature on adsorption properties.

TABLE 4: Thermodynamic parameters of uranium(VI) adsorption by modified rice stem.

\begin{tabular}{lccc}
\hline$T(\mathrm{~K})$ & $\Delta G^{0}(\mathrm{~kJ} / \mathrm{mol})$ & $\Delta H^{0}(\mathrm{~kJ} / \mathrm{mol})$ & $\Delta S^{0}[\mathrm{~J} /(\mathrm{mol} \cdot \mathrm{K})]$ \\
\hline 298 & -1.4883 & 9.4533 & 49.9505 \\
308 & -1.5383 & & \\
318 & -1.5882 & & \\
\hline
\end{tabular}

For the initial mass concentration, with $\ln K_{d}$ as the ordinate and $1000 / \mathrm{T}$ as the abscissa, a straight line can be obtained, the slope of the line is $-\Delta H / R$, and the vertical intercept of the line is $\mathrm{S}_{0} / R$.

As showed in Table 4, the negative free energy $\Delta G^{0}$ is less than zero, and $\Delta G^{0}$ decreases with the increasing temperature, indicating that the uranium adsorption process by rice stem is spontaneous, where the reaction is promoted by temperature. The enthalpy change $\left(\Delta H^{0}=9.4533\right)$ indicates an endothermic uranium adsorption. The positive entropy $\Delta S^{0}$ reflects the inconvertible process of adsorption uranium and little possibility of desorption. The three parameters illustrate that the adsorption process is a physical and chemical reaction.

\subsection{Adsorption Mechanism}

3.10.1. FT-IR Analysis. FT-IR spectra of samples are measured by Fourier infrared spectrum instrument which collects and analyzes scattered IR energy [38] (Figure 7). FT-IR spectra record the presence of different typical peaks which



FIGURE 7: FT-IR spectra of modified rice stem: (a) before adsorption of uranium(VI); (b) after adsorption of uranium(VI).

correspond to functional groups and surface properties. The curve a in Figure 7 shows the FT-IR spectrum of modified rice stem before adsorption of uranium. The widely strong peak observed at $3431 \mathrm{~cm}^{-1}$ is due to $\mathrm{O}-\mathrm{H}$ stretching vibration [28]. The band at $2912 \mathrm{~cm}^{-1}$ is formed as a result of C-H asymmetric stretching vibration of methyl and methylene groups in cellulose [4], whereas that at $2312 \mathrm{~cm}^{-1}$ is produced due to overtone or combination band of amino acids. The peak located at $1635 \mathrm{~cm}^{-1}$ indicates the stretching vibration of carbonyl groups from carboxylates and ketones [5]. The peak at $1433 \mathrm{~cm}^{-1}$ is due to $\mathrm{C}-\mathrm{H}$ bending vibration in lignin [39], while that at about $1026 \mathrm{~cm}^{-1}$ is attributed to C-O-C and asymmetric stretching vibrations of phosphate and silicate groups [39].

The curve $b$ in Figure 7 illustrates the FT-IR spectrum of modified rice stem after adsorption of uranium, which shows a slight shift. None of new bands appear, but the transmittance is reduced. It can be inferred that the structure of rice stem does not change after adsorption of uranium. The peaks at $3431,2912,2312,1635,1433$, and $675 \mathrm{~cm}^{-1}$ are shifted to $3429,2900,2310,1633,1381$, and $686 \mathrm{~cm}^{-1}$ after the adsorption of uranium, respectively, implying the replacement of some $\mathrm{H}^{+}$by $\mathrm{UO}_{2}{ }^{2+}$, which causes the decrease of the vibration strength and the absorption peak wavenumber $[40,41]$. The observed FT-IR spectra show that $\mathrm{O}-\mathrm{H}$, $\mathrm{C}=\mathrm{O}, \mathrm{Si}=\mathrm{O}$, and $\mathrm{P}-\mathrm{O}$ are the main adsorption sites in the uranium adsorption process.

3.10.2. EDS Analysis. The EDS can detect the difference in excited X-ray energies when the surface atoms of sample are bombard by the electron beam. The EDS images of modified rice stem before and after adsorption are shown in Figure 8. 


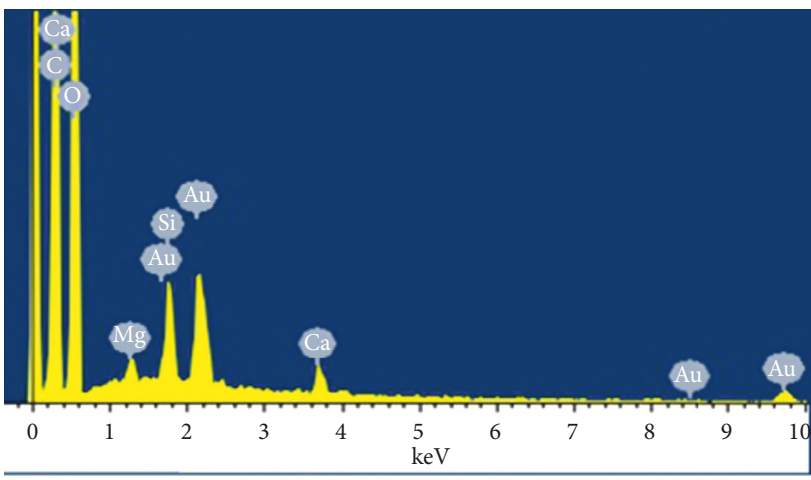

(a)

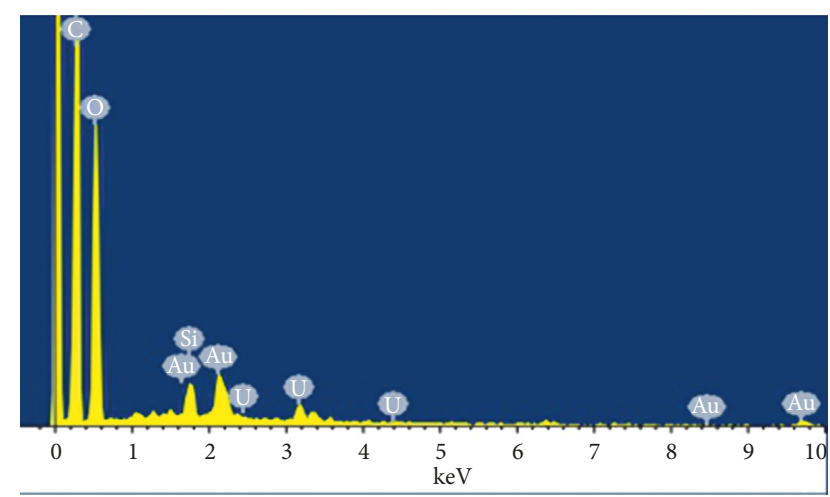

(b)

FIGURE 8: EDS analyses of modified rice stem: (a) before adsorption of uranium(VI); (b) after adsorption of uranium(VI).

The EDS images before adsorption of uranium (Figure 8(a)) show that the modified stem is composed of $\mathrm{C}, \mathrm{O}, \mathrm{Ca}, \mathrm{Si}$, and $\mathrm{Mg}$ elements. On the contrary, the EDS images after adsorption of uranium (Figure 8(b)) show the appearance of the $\mathrm{U}$ element and the decrease in the amounts of $\mathrm{Si}$ and $\mathrm{Ca}$ elements. These results indicate that the interaction of active groups of modified rice stem with uranium(VI) can cause a good adsorption of uranium(VI).

3.10.3. SEM Analysis. The SEM images of modified rice stem before and after adsorption of $\mathrm{UO}_{2}{ }^{2+}$ are shown in Figure 9, which indicates the variation in morphology of modified rice stem. For example, the images before adsorption show a rough surface of modified rice stem, with many voids in the distribution (Figure 9(a)). However, the distributed interstices and voids in the surface obviously decrease after adsorption, indicating a significant change in the surface morphology of rice stem (Figure 9(b)). This means that a large amount of $\mathrm{UO}_{2}{ }^{2+}$ is adsorbed by the rice stem in the adsorption process. The reason for this phenomenon may be because of (1) the interaction of $\mathrm{UO}_{2}{ }^{2+}$ with the functional organic groups (e.g., the hydroxyl group, carbonyl group, silicon oxygen bond (Si-O), and $\mathrm{P}-\mathrm{O}$ ) of the cell walls of rice stem $[28,37] ;(2)$ the exchange of $\mathrm{H}^{+}$on the surface with $\mathrm{UO}_{2}{ }^{2+}$; and (3) diffusion of free $\mathrm{UO}_{2}{ }^{2+}$ into the void of the stem.

3.10.4. XRD Analysis. The XRD images of the modified rice stem before and after adsorption of uranium(VI) are shown in Figure 10. The XRD result of the rice stem before adsorption represented by the curve a shows diffraction peaks at $2 \theta=15.64,22.08$, and 29.17, whereas that after adsorption shown in curve $\mathrm{b}$ illustrates the weaker diffraction peak at $2 \theta=15.64$, and 22.08, and even disappearance of the peak at $2 \theta=29.17^{\circ}$, implying that new crystals are not formed, and that the number of the crystal structure decreases in the adsorption process. This may be due to the adsorption of uranium(VI) by modified rice stem, which causes part of the molecule structures change from crystal to amorphous $[21,42]$.
3.11. Adsorption Process. Based on the results of FT-IR, SEM, EDS, and XRD mentioned above, we suggest that the adsorption process may be divided into the following 3 stages (Figure 11):

(1) $\mathrm{UO}_{2}{ }^{2+}$ migrates to the cell wall surface in solution

(2) $\mathrm{UO}_{2}{ }^{2+}$ reacts with active sites of the cell wall of rice stem

(3) $\mathrm{UO}_{2}{ }^{2+}$ deposites on the surface of the rice stem cell wall

\section{Conclusions}

This study presents a systematic investigation of the adsorption properties, such as the kinetics, thermodynamics, and mechanisms of modified rice stem. The following conclusions can be drawn:

(1) The rice stem treated with $0.5 \mathrm{~mol} / \mathrm{L} \mathrm{NaOH}$ solutions can effectively remove uranium(VI) from aqueous solution. $\mathrm{pH}=4.0$ is the best $\mathrm{pH}$ condition to remove uranium(VI). The removal percentage of uranium(VI) decreases with increasing initial concentration of uranium(VI).

(2) The sorption mode calculations using Langmuir, Freundlich, and Temkin isotherm models show that the maximum adsorption capacity of uranium by modified rice stem increases with temperature. Langmuir model, which indicates predominant monolayered adsorption of uranium, is better than Freundlich and Temkin models to describe the adsorption isotherm of uranium.

(3) The thermodynamic parameters $\Delta G^{0}, \Delta H^{0}$, and $\Delta S^{0}$ show that the adsorption of uranium(VI) is an endothermic and spontaneous process, where the temperature promotes the process. It is also suggested that the adsorption process is a physical and chemical reaction.

(4) The pseudo-second-order kinetic model, with the correlation coefficient of $R^{2}=0.9992$, fits the adsorption process of uranium(VI) much better than other kinetic models (e.g., pseudo-first-order kinetic 


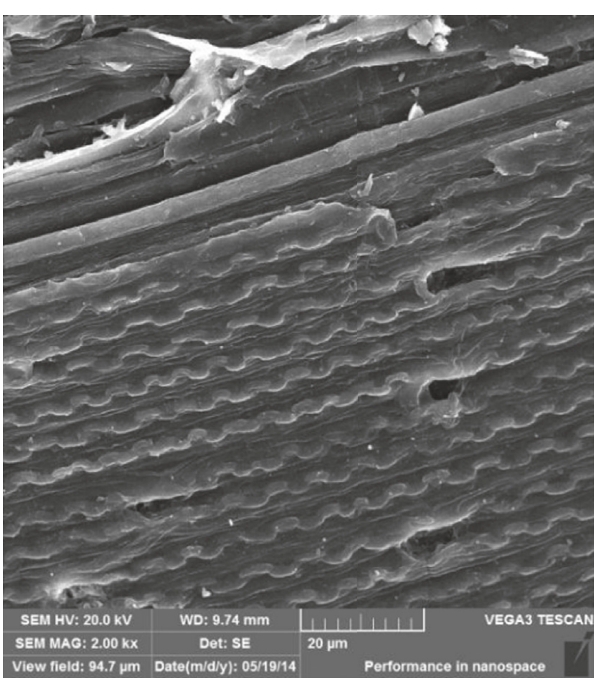

(a)

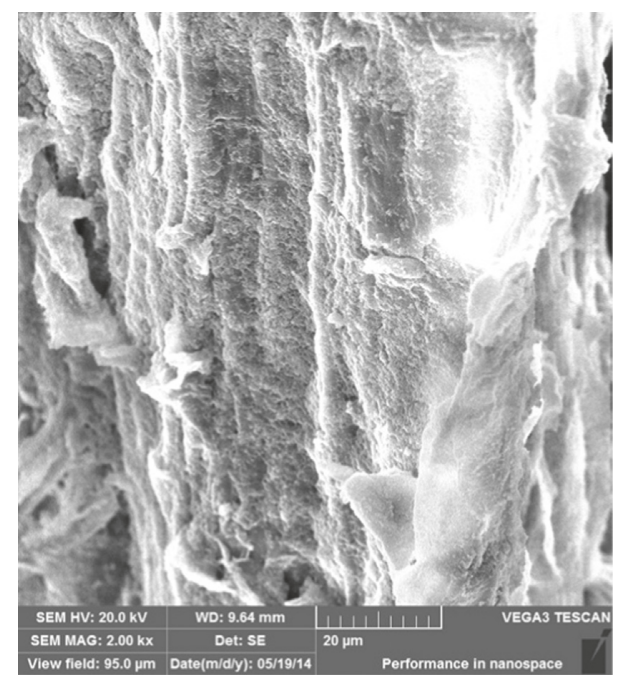

(b)

Figure 9: SEM images of modified rice stem: (a) before adsorption of uranium(VI) (2000x); (b) after adsorption of uranium(VI) (2000x).

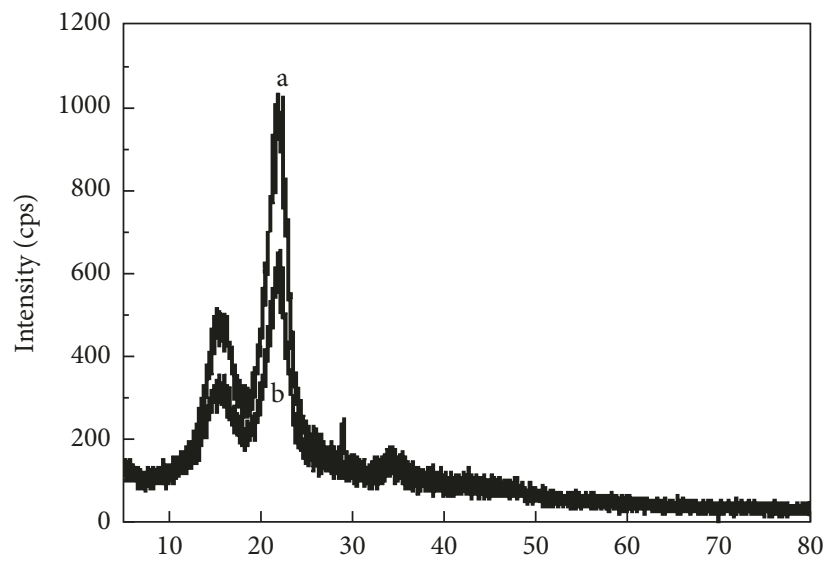

FIGURE 10: XRD images of modified rice stem: (a) before adsorption of uranium(VI); (b) after adsorption of uranium(VI).

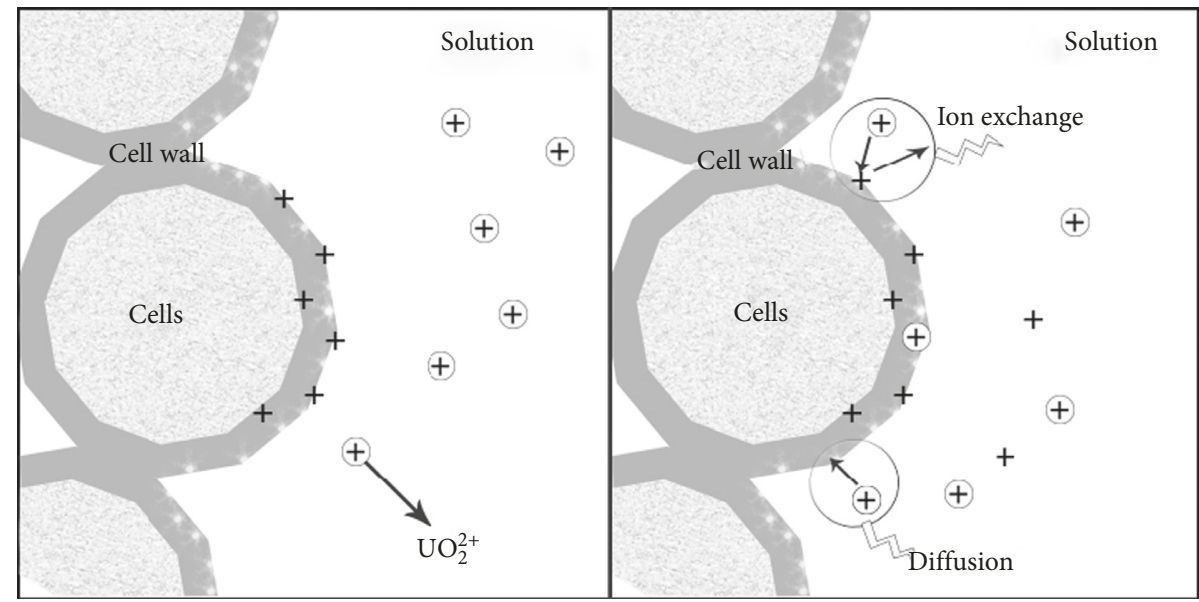

Figure 11: Adsorption process of uranium(VI) by modified rice stem.

model, pseudo-second-order kinetic model, Elovich kinetic model, and intraparticle diffusion model). (5) FT-IR and EDS analyses show that the interaction of the main adsorption sites $(\mathrm{O}-\mathrm{H}, \mathrm{C}=\mathrm{O}, \mathrm{Si}=\mathrm{O}$, and $\mathrm{P}-\mathrm{O})$ of modified rice stem with uranium(VI) can cause a good adsorption of uranium(VI). SEM and 
XRD analyses show that the surface morphology and the crystal structure of rice stem treated with $\mathrm{NaOH}$ solutions have significantly changed during the adsorption process.

\section{Data Availability}

This is a research article, and the data are from the experiment. All the data used to support the findings of this study are included within the article.

\section{Conflicts of Interest}

The authors declare that they have no conflicts of interest.

\section{Acknowledgments}

This project was supported by the National Natural Science Foundation of China (Grant no. 11575078).

\section{References}

[1] L. M. Camacho, S. Deng, and R. R. Parra, "Uranium removal from groundwater by natural clinoptilolite zeolite: effects of $\mathrm{pH}$ and initial feed concentration," Journal of Hazardous Materials, vol. 175, no. 1-3, pp. 393-398, 2010.

[2] H. Parab, S. Joshi, N. Shenoy, R. Verma, A. Lali, and M. Sudersanan, "Uranium removal from aqueous solution by coir pith: equilibrium and kinetic studies," Bioresource Technology, vol. 96, no. 11, pp. 1241-1248, 2005.

[3] S. Xiaoliang and Q. Gongwang, "The hazard of the radioactive contamination and the preventive methods," Industrial Safety and Dust Control, vol. 30, no. 1, pp. 6-9, 2004.

[4] V. Baran, L. Šourková, and J. Spalová, "Water-free precipitation uranate with maximum sodium content, $\mathrm{Na} /$ $\mathrm{U}=1.0$," Journal of Radioanalytical and Nuclear Chemistry Letters, vol. 95, no. 5, pp. 331-338, 1985.

[5] P. M. Mapara, A. G. Godbole, R. Swarup, and M. S. Nagar, "Extraction of uranium and plutonium from oxalate bearing solutions using phosphonic acid: solvent extraction, extraction chromatography and infrared studies," Journal of Radioanalytical and Nuclear Chemistry, vol. 240, no. 2, pp. 631-635, 1999.

[6] N. T. El-Hazek and M. S. El Sayed, "Direct uranium extraction from dihydrate andhemi-dihydrate wet process phosphoric acids by liquid emulsion membrane," Journal of Radioanalytical and Nuclear Chemistry, vol. 257, no. 2, pp. 347-352, 2003.

[7] W. Liu, X. Dai, Z. L. Bai et al., "Highly sensitive and selective uranium detection in natural water systems using a luminescent mesoporous metal-organic framework equipped with abundant lewis basic sites: a combined batch, X-ray absorption spectroscopy, and first principles simulation investigation," Environmental Science \& Technology, vol. 51, no. 7, pp. 3911-3921, 2017.

[8] L. Y. Yuan, L. Zhu, C. L. Xiao et al., "Large-pore 3D cubic mesoporous (KIT-6) hybrid bearing a hard-soft donor combined ligand for enhancing U(VI) capture: an experimental and theoretical investigation," ACS Applied Materials \& Interfaces, vol. 9, no. 4, pp. 3774-3784, 2017.

[9] D. X. Gui, T. Zheng, L. H. Chen et al., "Hydrolytically stable nanoporous thorium mixed phosphite and pyrophosphate framework generated from redox-active ionothermal reactions," Inorganic Chemistry, vol. 55, no. 8, pp. 3721-3723, 2016.

[10] J. Wang and C. Chen, "Biosorption of heavy metals by Saccharomyces cerevisiae: A review," Biotechnology Advances, vol. 24 , no. 5, pp. 427-451, 2006.

[11] N. P. Barkley, "Extraction of mercury from groundwater using immobilized algae," Journal of the Air \& Waste Management Association, vol. 41, no. 10, pp. 1387-1393, 1991.

[12] D. W. Darnall, B. Greene, M. T. Henzl et al., "Selective recovery of gold and other metal ions from an algal biomass," Environmental Science \& Technology, vol. 20, no. 2, pp. 206-212, 1986

[13] E. Fourest and J. C. Roux, "Heavy metal biosorption by fungal mycelial by-products: mechanisms and influence of $\mathrm{pH}$," Applied Microbiology \& Biotechnology, vol. 37, no. 3, pp. 399-403, 1992.

[14] N. Goyal, S. C. Jain, and U. C. Banerjee, "Comparative studies on the microbial adsorption of heavy metals," Advances in Environmental Research, vol. 7, no. 2, pp. 311-319, 2003.

[15] T. Takehiko, "Adsorption of uranium from acidic solution by microbes and effect of thorium on uranium adsorption by Streptomyces levoris," Journal of Bioscience and Bioengineering, vol. 97, no. 4, pp. 275-277, 2004.

[16] S. Ilhan, M. N. Noubakhsh, S. Kilicarslan, and H. Ozdag, "Removal of chromium, lead and copper ions from industrial waste water by Staphylococcus saprophyticus," Turkish Electronic Journal of Biotechnology, vol. 2, pp. 50-57, 2004.

[17] G. Ozdemir, N. Ceyhan, T. Ozturk, F. Akirmak, and T. Cosar, "Biosorption of chromium (VI), cadmium (II) and copper (II) by Pantoea sp. TEM 18," Journal of Chemical Engineering, vol. 102, no. 3, pp. 249-253, 2004.

[18] S. Y. Kang, J. U. Lee, and K. M. Kim, "Biosorption of Cr (III) and $\mathrm{Cr}$ (VI) onto the cell surface of Pseudomonas aeruginosa," Journal of Biochemical Engineering, vol. 36, no. 1, pp. 54-58, 2007.

[19] W. Zou, L. Zhao, and L. Zhu, "Adsorption of uranium (VI) by grapefruit peel in a fixed-bed column: experiments and prediction of breakthrough curves," Journal of Radioanalytical and Nuclear Chemistry, vol. 295, no. 1, pp. 717-727, 2013.

[20] S. Bagherifam, A. Lakzian, S. J. Ahmadi, M. F. Rahimi, and A. Halajnia, "Uranium removal from aqueous aqueous solutions by wood powder and wheat straw," Journal of Radioanalytical and Nuclear Chemistry, vol. 283, no. 2, pp. 289-296, 2010.

[21] L. Xia, K. Tan, X. Wang, W. Zheng, W. Liu, and C. Deng, "Uranium removal from aqueous solution by banyan leaves: equilibrium, thermodynamic, kinetic, and mechanism studies," Journal of Environmental Engineering, vol. 139, no. 6, pp. 887-895, 2013.

[22] J. Goel, K. Kadirvelu, C. Rajagopal, and V. K. Garg, "Investigation of adsorption of lead, mercury and nickel from aqueous solutions onto carbon aerogel," Journal of Chemical Technology \& Biotechnology, vol. 80, no. 4, pp. 469-476, 2010.

[23] L. Liu, Study of Modified Straw Adsorbent Characterization and Adsorption Performance of Dealing with Methylene Blue Solution, Chongqing University, Chongqing, China, 2011.

[24] M. N. Amin, A. I. Mustafa, M. I. Khalil, M. Rahman, and I. Nahid, "Adsorption of phenol onto rice straw biowaste for water purification," Clean Technologies and Environmental Policy, vol. 14, no. 5, pp. 837-844, 2012.

[25] S. Sugashini, "Preparation of activated carbon from carbonized rice husk by ozone activation for $\mathrm{Cr}(\mathrm{VI})$ removal," New Carbon Materials, vol. 30, no. 3, pp. 252-261, 2015. 
[26] X. Q. Xiong, H. D. Liao, J. S. Ma et al., "Isolation of a rice endophytic bacterium, $\mathrm{P}$ antoea sp. Sd-1, with ligninolytic activity and characterization of its rice straw degradation ability," Letters in Applied Microbiology, vol. 58, no. 2, pp. 123-129, 2014.

[27] J. Yao, X. W. Xu, and Y. Y. Feng, "FTIR studies on the chemical composition of wheat straw in different layers," Spectroscopy and Spectral Analysis, vol. 23, pp. 58-60, 2003.

[28] X. Wang, L. Xia, K. Tan, and W. Zheng, "Studies on adsorption of uranium (VI) from aqueous solution by wheat straw," Environmental Progress \& Sustainable Energy, vol. 31, no. 4, pp. 566-576, 2012.

[29] A. Esposito, F. Pagnanelli, and F. Vegliò, "pH-related equilibria models for biosorption in single metal systems," Chemical Engineering Science, vol. 57, no. 3, pp. 307-313, 2002.

[30] H. B. Yang, N. Tan, F. J. Wu et al., "Biosorption of uranium (VI) by a mangrove endophytic fungus Fusarium sp.\#ZZF51 from the South China Sea," Journal of Radioanalytical and Nuclear Chemistry, vol. 292, no. 3, pp. 1011-1016, 2012.

[31] K. V. Kumar and S. Sivanesan, "Pseudo second order kinetics and pseudo isotherms for malachite green onto activated carbon: comparison of linear and non-linear regression methods," Journal of Hazardous Materials, vol. 136, no. 3, pp. 721-726, 2006.

[32] C. Valderrama, J. L. Cortina, A. Farran, X. Gamisans, and C. Lao, "Kinetics of sorption of polyaromatic hydrocarbons onto granular activated carbon and Macronet hyper-crosslinked polymers (MN200)," Journal of Colloid and Interface Science, vol. 310, no. 1, pp. 35-46, 2007.

[33] S. Tunali, T. Akar, A. S. Özcan, I. Kiran, and A. Özcan, "Equilibrium and kinetics of biosorption of lead (II) from aqueous solutions by cephalosporium aphidicola," Separation and Purification Technology, vol. 47, no. 3, pp. 105-112, 2006.

[34] R. Ahmad, "Sawdust: cost effective scavenger for the removal of chromium (III) ions from aqueous solutions," Water, Air, and Soil Pollution, vol. 163, no. 1-4, pp. 169-183, 2005.

[35] B. Özkaya, "Adsorption and desorption of phenol on activated carbon and a comparison of isotherm models," Journal of Hazardous Materials, vol. 129, no. 1-3, pp. 158-163, 2006.

[36] K. Vijayaraghavan, T. V. N. Padmesh, K. Palanivelu, and M. Velan, "Biosorption of nickel (II) ions onto sargassum wightii: application of two-parameter and three-parameter isotherm Models," Journal of Hazardous Materials, vol. 133, no. 1-3, pp. 304-308, 2006.

[37] S. Yusan and S. Erenturk, "Behaviors of uranium (VI) ions on $\alpha$-FeOOH,” Desalination, vol. 269, no. 1-3, pp. 58-66, 2011.

[38] P. Ilaiyaraja, A. K. Singha Deb, K. Sivasubramanian, D. Ponraju, and B. Venkatraman, "Adsorption of uranium from aqueous solution by PAMAM dendron functionalized styrene divinylbenzene," Journal of Hazardous Materials, vol. 250-251, pp. 155-166, 2013.

[39] J. Bai, H. Yao, F. Fan et al., "Biosorption of uranium by chemically modified Rhodotorula glutinis," Journal of Environmental Radioactivity, vol. 101, no. 11, pp. 969-973, 2010.

[40] D. Shubo and T. Yenpen, "Characterization of PEI-modified biomass and biosorption of $\mathrm{Cu}$ (II) and Ni (II)," Water Research, vol. 39, no. 10, pp. 2167-2177, 2005.

[41] L. S. Sheng, W. Li, and W. Aiqin, "Adsorption properties of cross-linked carboxymethl-chitosan resin with $\mathrm{Pb}(\mathrm{II})$ as templates ions," Journal of Hazardous Materials, vol. 136, no. 3, pp. 930-937, 2006.
[42] J. Man, J. Cai, F. Zhang, Q. Liu, and C. Wei, "Spectrum analysis of crystalline structure of crop starches," Acta Agronomica Sinica, vol. 38, no. 4, pp. 691-698, 2013. 



Physical Chemistry
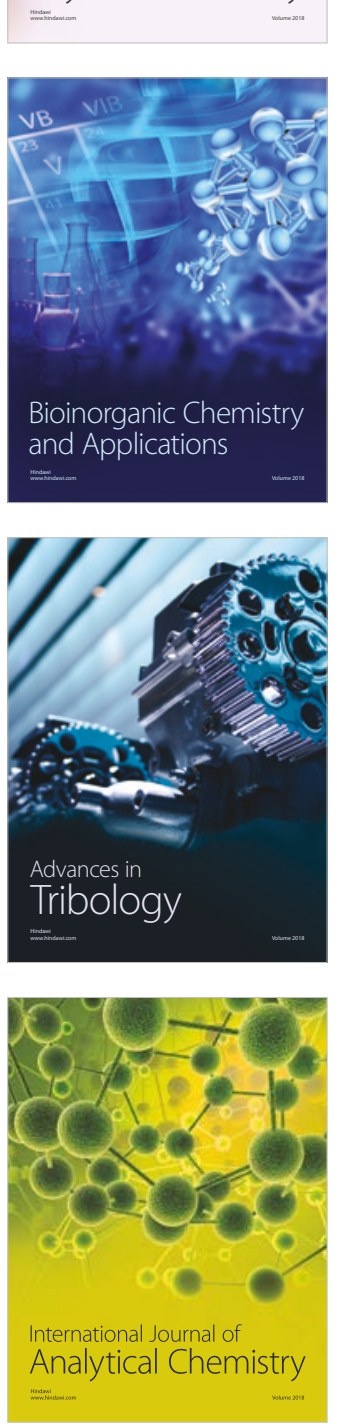

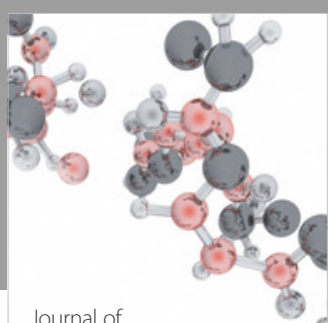

Analytical Methods

in Chemistry



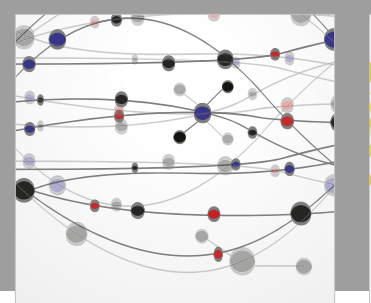

The Scientific World Journal

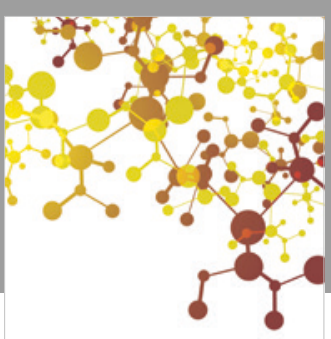

Journal of

Applied Chemistry


Submit your manuscripts at

www.hindawi.com
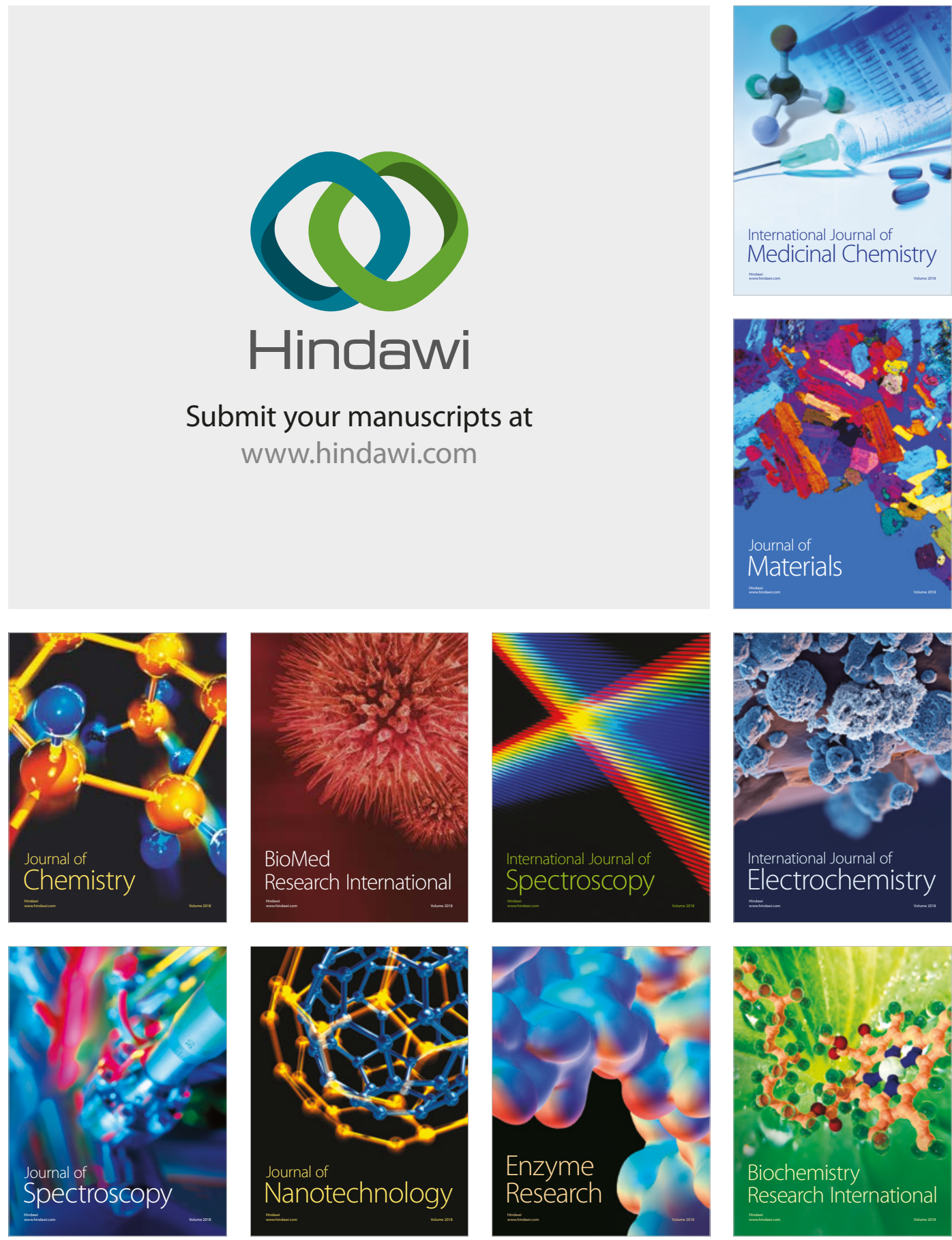
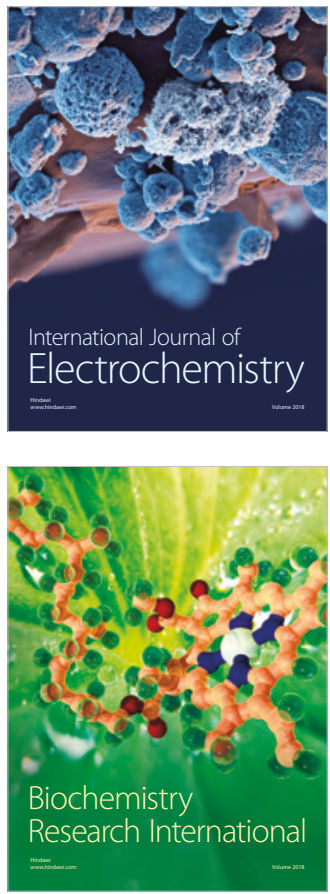